\title{
Innovative approach for technology dissemination among rural community -By KVK, Ambala
}

\author{
UPASANA SINGH*, PRAGATI SINGH AND RAMESH KUMAR \\ Krishi Vigyan Kendra, AMBALA(HARYANA) INDIA
}

\begin{abstract}
Farm Women of Rural areas generally face lots of problems during their day- to- day life. These problems can be as drudgery burden; high cost; time; energy; fuel consuming and above to all, the problem of health and hygiene. To mitigate these problems to some extent, KVK Ambala innovated some technologies such as Janta Water Filter, Ice-less refrigerator, bhusse ka dibba and hand cloth washing device. These innovations work on different principles. Janta Water Filter work on filtering candle which filters water instantly. This filter can be used to remove suspended particles and harmful bacteria from polluted water. Ice-less refrigerator works without electricity and on the principle that evaporation causes cooling effect. Bhusse ka dibba works on the principle of the thermal insulation which resist the flow of heat from the inside to outside and thereby save and store thermal energy. It keeps food hot for 6-8 hrs. Hand cloth washing device is based on the principle of centrifugal force. Various trainings, trials and demonstrations and extension activities were organized for Aanganwadies workers(120), School's children(30) and Farm women (850) to disseminate these technologies purposively in selected villages of all 6 blocks of Ambala district of Haryana. After testing these innovations, feed-back were collected from different sources (i.e. schools, Aangawadi Kendra and Farm Women) and overall impression was that these innovations are user friendly, sustainable, ecologically viable, drudgery reducing, low costing, time, energy and fuel saving. There is need to promote these technologies on a larger scale specially in rural areas of other states.
\end{abstract}

KeY Words : Drudgery, Technologies, Innovations, Sustainable, Ecologically viable

View Point Article : Singh, Upasana, Singh, Pragati and Kumar, Ramesh (2016). Innovative approach for technology dissemination among rural community -By KVK, Ambala. Internat. J. Home Sci. Extn. \& Comm. Manage., 3 (1): 15-20.

Article History : Received : 27.07.2015; Revised : 08.12.2015; Accepted : 22.12.2015

* Author for correspondence (Email : kvkambala@gmail.com; upasanararathee@rediffmail.com) 